the thirty cases of cholera treated in his hospital. In every case the source of infection had been traced to the water used for drinking. Fifteen cases were cured, and, of these, five had such slight symptoms that but for the bacteriological test they would never have been taken for cholera patients. On the other hand, many cases of cholera nostras observed by Guttmann were of an extremely severe type, with symptoms in every way resembling those of Asiatic cholera. Here, too, it was the bacteriological examination that fixed the diagnosis. Guttmann spoke favourably of subcutaneous injection of salt solution, which, though by no means a "cure" (Heilmittel), were useful in tiding over the dangerous stage of asphyxia. Salol and creolin had proved useless. Careful bacteriological examinations proved that recovered cases were free from bacilli between the fifth and tenth day.

Fruit and the Cholera Bacilli.

The Imperial Cholera Commission has been carrying on experiments with a view to finding out how long cholera bacilli can live in fruit, vegetables, and various drinks. They have found that, at ordinary temperature, the bacilli die in from one to two hours in the substance of fruit, the acidity of which is more than 2 per cent. (for instance, red and white currants). In Italian peaches, sour cherries, plums, apples, and some sorts of pears, they lived from three to six hours, whilst in apricots, strawberries, gooseberries, and greengages they lived for twenty to twenty-four hours, and for several days in sweet cherries, pears, some kinds of plums, and cucumbers. On the outside of fruit and cucumber cholera bacilli live much longer, and, if the surface be damp, they will live as long as from five to seven days on currants, cherries, etc., unless exposed to direct sunlight, when they die in a few hours. Wine -claret or hock-was found to kill the bacilli in a few minutes, and cold infusions of tea and coffee, beer, and boiled milk in periods varying from one hour (for tea) to several days. On salt and smoked herring the bacilli lived almost twenty-four hours, and on fresh fish almost two days.

\section{The RHINe.}

Examination stations have been established for the Rhine waterways at Mannheim, Ludwigshafen, and Mayence, and also at various places in the Oder district.

\section{Old Clothes.}

A man and woman, who some weeks ago smuggled into Wandsbeck and there sold clothes from a cholera house in Hamburg, thereby causing the death of three persons, have been sentenced to two years' imprisonment.

\section{BELGIUM.}

On October 13th a report was laid before the Superior Council of Health by the Director of the Sanitary Service, M. Beco. Between July 21 st and October 1st, 1,135 cases of cholera, with 564 deaths, have been reported to the authorities. In the port of Antwerp there were 244 cases and 89 deaths. With the exception of Antwerp, the places where the visitation has been most marked are those which communicate with our metropolis by water. In the provinces the list stands thus: (1) Antwerp, 702 cases and 326 deaths ; (2) Flandre Orientale, 199 cases and 118 deaths ; (3) Flandre Occidentale, 121 cases and 15 deaths ; (4) Hainault, 113 cases and 54 deaths; (5) Brabant, 85 cases and 44 deaths. The provinces of Liege, of Limbourg, of Luxembourg, and Namur, further removed from the centre of contagion and possessing the purest drinking water, have been very slightly attacked. At the conclusion of his report M. Beco demanded the relorm The local authorities, who are free at present to take the most efficacious measures in their power to check contagion, and who too often neglect this duty, especially in the country districts, are to be compelled to act with It is also deemed advisable to improve the system of disinfection and to purify the water supply, especially in the quarters of the labouring purify the water supply, especially in the quarters of the labouring
classes, who have been almost the only victims of the scourge. M. Beco's report shows the futility of restrictive measures at the frontier. A sounder legislation and the diffusion of a better understanding of the simplest rules of hygiene are far surer safeguards against the evil.

$$
\text { FRANKFORT-ON-THE-MAIN. }
$$
Two cases of Asiatic cholera are reported from Frankfort-on-the-Main.
The sufferers who have imported the disease into the city are, as was also the case in Berlin, barge people. They come from Holland. The water of the Main is declared to be polluted.

\section{HAMBURG.}

The total registrations of cholera now amount to 17,962 cases, of which 7,598 ended fatally.

The Advisory Committee of the Sanitary Board of Paris on October 17th heard Dr. Brouardel's report upon his recent journey to Marseilles. He declared that the cholera outbreak there was principally due to the contamination of drinking water by sewerage. Measures necessary to remove this danger had been taken, and the hope was justified that the ep demic was nearly at an end.

\section{NOTES ON HEALTH RESORTS.}

$$
\text { X.-EGYPT. }
$$

By F. M. Sandwith, M.D.,

Physician to the Kasr-el-Aini Hospital, Cairo; and formerly Vice-Director of the Sanitary Department of Egypt.

Cases which Derive Bengfit from a Winter Residence in EgYPT.

CAIRo is rapidly growing in public favour as a winter resort, owing to the pure desert air, which acts as a tonic, the absence of rain, fog, snow, strong winds, and extreme cold the very complete historical remains, and the modern fruits of English civilisation. The patients who may safely be recommended to winter in Egypt are the asthmatic, those troubled. with incipient, quiescent, or chronic diseases of the chest, sufferers from rheumatism in all forms, and nearly every other chronic disease. Patients suffering from rheumatoid arthritis are a little better off in Egypt than in other wintering places, and this is all that can be said. A dry climate is of value to patients with kidney disease, because the skin does the greatest part of the elimination, and the renal organs get a corresponding rest.

\section{Contra-Indications and Drawbacks.}

The cases which should not be sent to Egypt are those suffering from febrile or very advanced lung disease, those afflicted with extremely advanced disease of heart or other organ; those with a very limited supply of money, and those with chronic home sickness. There are many drawbacks to wintering on the Nile besides expense and the distance of six days from London. Insect life is very apparent in the form of flies, fleas, and mosquitos, all requiring some cleverness of management. As regards food, we have very fair mutton and. beef, good poultry, excellent ducks, snipe, and quail, indifferent bread and cow's milk, perfect fresh butter, doubtful eggs, and a delicious variety of vegetables and fruit.

Season AND Route.

Visitors are advised not to reach Egypt before November which is one of the best months in the year. Until the railway from Port Said to Ismailia is completed, they are recommended to land by way of Alexandria, thus avoiding all risk of exposure to night air and bad trains. Patients with lung disease should not leave Egypt till the end of April, at least; and rheumatic patients should stay in Cairo till the end of May, or even later, to get the full benefit of dry heat. When Cairo becomes too hot, Ramleh-a seaside suburb of Alexandria-is recommended as a suitable place for a week or two on the way back to Europe. Intending visitors should err on the side of bringing too much, rather than too little, warm clothing; for the cold after sunset in January, especially on the Nile, is intense.

\section{RaInfall, Temperature, and Winds.}

November, already praised, is a rainless month. In December the invalid will be subjected to an average maximum heat out of doors of $69^{\circ} \mathrm{F}$, in January $67^{\circ}$, in February $68^{\circ}$, in March $76^{\circ}$, in April $84^{\circ}$, and in May $92^{\circ}$. The average minimum temperature by night out of doors does not concern the invalid, but he ought to be greatly interested in his bedroom minimum heat. In Cairo this need never fall below $63^{\circ}$, while in April it rises to $68^{\circ}$, and in May to $72^{\circ}$. Rain falls on an average three days in the month in Cairo between December and April, but the whole rainfall of the year is only $1 \frac{1}{4}$ inch. In February there begins usually a dry, dusty, desert wind, which reaches its maximum (seven days in the month) during April. It is not unwholesome except to the temper, but it is a decided nuisance, and sometimes lasts three days at a time.

\section{Water Supply and Sanitary Arrangements.}

The Nile water, when carefully filtered, is excellent to drink. Ice is made from distilled water by the water company. A drainage scheme will be commenced next summer at present the best hotels and houses frequented by the English are furnished with cemented cesspools outside the house, carefully trapped and ventilated, and emptied by an odourless pneumatic system. The mosques and bazaars are all insanitary. 
NuRses aNd Hosprtals.

Several English nurses can now be obtained in Cairo; there are also good masseurs, and a small English private hospital.;

[Helodan : the Pyramids and Luxor.

Helouan is a suburb of Cairo where rheumatic and skin patients can take sulphur baths closely resembling those of Aix-les-Bains during the winter, when it is too cold to do so in Europe. Life is very quiet, the air exhilarating, and an excellent hotel has just been opened there. At the Pyramids there are many similar attractions, but no sulphur baths. Besides the Sphinx and Pyramids themselves, there is a constant stream of pleasure-seeking visitors in addition to the searchers after health. Luxor is $\mathbf{4 5 0}$ miles south of Cairo, and can be reached by various steamers and Nile boats, while the railway line is being gradually extended to $\mathrm{it}$. The climate is perfect during January and February. There is no rain ; the air is almost the driest in the world, and the temperature, though cold at night, is delightful by day, being something like that of Cairo in February and March respectively. Thebes and Karnak are both within easy donkey riding distance from Luxor.

\section{THE FIVE YEARS' CURRICULUM.}

The Opintons of the Rev. Dr. Hadghton, M.D. AND Mr. Mitchell Banks.

We are favoured, in reply to a communication which we some time since addressed to them, with following observations from experienced members of the General Medical Council, upon the best means of utilising the extra year which has now been added to the compulsory medical curriculum. It will be seen that both Dr. Haughton and Mr. Mitchell Banks have come to very similar conclusions :

Dr. Samogl Hadghton, F.R.S. (Trinity College, Dublin), writes :

Out-Patient Practice.-In my opinion the fifth year would be best spent in general and special hospital work, especially in an hospital where there is a large out-patient department, worked diligently by younger men well acquainted with the needs of medical students of to-day, and able to take advantage of their improved medical education.

The First Year.-It seems to me that the first year requires more attention than the fifth. My experience is that, from want of knowledge of mechanics, physics, chemistry, and natural history, the average medical student is quite unprepared to enter upon the purely professional part of his education, such as anatomy, physiology, and the study of the physical signs of health and disease.

The Choice of a General Practitioner.-I would not accept certificates of six months' teaching from any general practitioner who had not an establishment of at least fifty beds under his control, including fever cases and common diseases of children. I do not believe that six months under a general practitioner will ever be popular in Ireland.

Professor W. Mrtchell Banks (University College, Liverpool) writes :-

Special Subjects.-If the student has worked properly and has passed his earlier examinations at the appropriate periods, he should, by the end of his fourth year, have completed the necessary lectures and hospital attendance pertaining to general surgery and general medicine. I therefore think that the fifth year should be devoted as much as possible to special subjects. In every place where a medical school exists there also exist abundant facilities for the study of such special subjects. I would especially mention diseases of the eye and ear, children's diseases (as seen in a children's hospital or children's ward of a general hospital), diseases of women, skin diseases, mental diseases, typhus and typhoid fever, and hygiene. I am quite sure that in two winter terms and one summer term of three months each an industrious student could obtain a great deal of useful knowledge of these subjects. I do not mean to say that he would become an expert oculist in three months, but, at all events, he would learn to know when a dangerous state of things was impending, and would not go on blundering with a serious eye case unaided and ignorant of its real gravity until all chance of saving sight was lost. A general practitioner must have a very good knowledge of some things, and a smattering of everything else beside. I am sure that he can never be provided with more than a mere smattering, unless his curriculum is to be prolonged to seven or eight years. But that smattering may include the knowledge of certain sound broad principles which in after-life may save him from making a fool of himself and doing damage to his patient. I think that the special subjects above mentioned can and should be learnt in special hospitals, in special wards of general hospitals, or in workhouse infirmaries, and that they should be studied under trained teachers.

Foreign Study. As to the question of the student going abroad for special work, I do not think it a wise thing. He can get more than enough of good instruction at home. His going abroad should be done after he has qualified and when he no longer has the fear of examinations hanging over his head. Besides, when a little older, he studies with discrimination and is not so likely to be led away into mere idle or pleasure-loving habits.

Pupilage.-As to the great question of whether six months of the fifth year can be best spent in pupilage, I do not think they can. Nothing is so valuable to a student as being trained in the first instance to observe methodically and then to reason logically upon what he has observed. If once he has acquired this power then he goes on teaching himself for the rest of his days. A pupil receives no such methodical training. He is occupied in "picking up" practical details which are without doubt useful but of which a knowledge can be gained at any later time. But the power of closely observing and carefully reasoning can only be learnt when a man is a student and only from persons who can observe and reason well themselves, that is to say from trained teachers.

Common Diseases and Prescribing.-The main argument for pupilage is that the student, having obtained his degree or qualification, enters into practice extremely ignorant of many common diseases, such as scarlatina, measles, whoopingcough, chicken-pox, scabies, and the other troubles which form the bulk of general practice. Moreover, he is very ignorant of the so-called art of prescribing. I am firmly of opinion that the only way he can get over this difficulty is to go as an assistant to a general practitioner after he has qualified. This is the proper time for him to pick up the details and small, though most necessary, arts of private practice, including the "bedside manner." All these things are soon learnt, and can be learnt at any time; but, to my way of thinking, any part of a five years' curriculum is far too valuable to be thrown away upon them. Every month of it can be spent in a mental training which can never be acquired at a later period. Without that special training a man never advances in after-life, but plods along by rule-of-thumb, neither improving himself nor his art. Furthermore, having. after twenty-seven years' experience, a pretty good idea of where and how a student is to learn his work, I cannot think it possible for him to get a knowledge of what are termed common diseases except by seeing them in actual practice, and the controversy hinges upon whether it is hest for him to study these diseases before or after he is qualified. I know very well that doctors who want qualified assistants are indignant because the gentlemen who come to them nowadays know nothing of general practice, and are very useless until they have acquired a knowledge of it. They expect them to be of the type of the fast-disappearing unqualified assistant, who was a kind of useful helot. But this cannot be in the future. What will probably happen is this: On the one hand, the practitioner, if he takes a qualified assistant fresh from the schools, will simply have to recognise the fact that the said assistant will not be of much use to him for some months. On the other hand, the assistant will have to recognise the fact that he cannot for a while be of much good in the "business" part of his master's work, and must at first be content with mere bed and board by way of remuneration; he will have, in fact, to regard a first assistantship as merely an extension of his curriculum. I see no other way for it.

Permissive Pupilage. - With these views it may be fairly asked why I voted in the General Medical Council for allowing the student, if he wished, to spend six months out of his fifth year as a pupil. For the following reasons: (1) Because it was represented to the Council that a large body of general 